\title{
Járadékteremtés és az áldemokráciák
}

Tanulmányunkban egy olyan rendszerrel foglalkozunk, amely köztes helyet foglal el a demokrácia és az autokrácia között, mindkettő jegyeit magán viseli, és amelyet ezért áldemokráciának nevezünk. A rendszer müködési sajátosságait a járadékok szemszögéből vizsgáljuk, és arra keressük a választ, hogy demokratikus országokban hogyan képes egy párt tartósan domináns pozícióban maradni. Modellünk segítségével összekapcsoljuk a járadékteremtést a szavazatok maximalizálásának céljával, és bemutatjuk, miért jelenthet racionális döntést a hatalmon lévők számára a rövid távú optimumon túlmutató járadékteremtés is. A modell rávilágít arra, hogy a többletjáradékok segítségével a kormányzat - klientúrája megerősítése, a demokratikus rendszer határainak feszegetése, valamint az ellenzék visszaszorítása révén - hosszú távú előnyökre tehet szert, áldemokráciát hozva létre. Történelmi példák jól mutatják, hogy a rendszer bukását végül általában a gyengébb gazdasági teljesítmény és a korrupció széles körüvé válása kényszeríti ki. Journal of Economic Literature (JEL) kód: D72, P16.

\section{Bevezetés}

Az elmúlt években megnőtt azoknak a publikációknak a száma, amelyekben (elsősorban Zakaria [1997] nyomán) a demokrácia átalakulásáról, az illiberális állam megjelenéséröl és térhódításáról, valamint általánosságban is a nyugati típusú demokrácia fenntarthatatlanságáról és idejétmúltságáról írnak. Ez a jelenség szöges ellentétben áll azzal a már-már euforikus optimizmussal, amely az 1980-as évek végén, 1990-es évek elején kerítette hatalmába a társadalomtudósokat, és amelynek kapcsán a történelem végét (Fukuyama [2014/1992]) és a demokrácia mindenhatóvá válását vizionálták. Úgy tünik azonban, ezek a jóslatok nem váltak valóra, hiszen a demokrácia azóta sem vert gyökeret világszerte, és bár sok helyütt megkísérelték bevezetni valamilyen formában, e próbálkozások sem vezettek mindig sikerre. Az igazság ezzel szemben

\footnotetext{
Székely-Doby András a Budapesti Corvinus Egyetem Összehasonlító és Intézményi Gazdaságtan Tanszékének adjunktusa (e-mail: andras.szekely-doby@uni-corvinus.hu).

A kézirat első változata 2015. március 20-án érkezett szerkesztőségünkbe.

DOI: http://dx.doi.org/10.18414/KSZ.2016.5.501
} 
az, hogy néhány kivételtől eltekintve jól működő demokráciákkal továbbra is csak a legfejlettebb nyugati világban találkozhatunk.

Ugyancsak egyre népszerübbek azok a írások, amelyek a gazdasági teljesítményt az intézményi berendezkedéssel, közelebbről a politikai intézményekkel kapcsolják össze. Acemoglu-Robinson [2013] vagy North és szerzötársai [2009] - hogy csak néhányat említsünk közülük - vizsgálódásai elsősorban arra irányulnak, hogy összefüggéseket tárjanak fel különböző országok intézményi megoldásai és gazdasági teljesítményei között, és megmutassák, hogy bizonyos intézmények nagyobb valószínűséggel vezetnek társadalmi szinten hatékonyabb kimenetelekhez (több innovációhoz, gyorsabb növekedéshez stb.), mint mások. Érdekes azonban, hogy ez utóbbi gondolatkört képviselő szerzők érvelése szerint pontosan azok a demokratikus intézmények lehetnek hosszú távon is sikeresek, amelyek meghaladásáról a korábbiakban említett publikációkban értekeztek.

Kevesebben foglalkoznak ugyanakkor azzal a fordított problémával, hogy a gazdasági teljesítmény és a gazdaság legfontosabb intézményei által meghatározott folyamatok milyen hatással lehetnek a politikai szférára, annak intézményi megoldásaira, a hatalmi viszonyok alakulására, a különböző rendszerek stabilitására, valamint a rendszerek közötti átmenet feltételeire és lehetöségeire. Különösen érdekes ez a kérdés olyan országok esetében, ahol a gazdaság és a politika közötti összefonódás erős, és nemcsak a politikai berendezkedés befolyásolja jelentős mértékben a gazdasági teljesítményt, hanem a gazdaság erőforrásainak elosztási és felhasználási módjai is nagymértékben visszahatnak a politikai struktúrára. Ezekben az országokban általában vagy autokratikus, vagy csak részben demokratikus politikai rendszerek müködnek, a gazdaságban pedig számos olyan intézmény játszik kiemelkedően fontos szerepet, amelyeket Acemoglu-Robinson [2013] 76. o.) kizsákmányoló típusúnak nevez. Tanulmányunk a politika és a gazdaság kölcsönhatásait olyan rendszerekben vizsgálja, amelyek a demokrácia és az autokrácia között helyezkednek el, és arra keres választ, miként befolyásolja a hatalomhoz szükséges erőforrások - járadékok - megszerzése és elosztása a kialakuló politikai struktúrát.

A kormányzat (az elit) járadékteremtési gyakorlatát és járadékpolitikáját demokratikus keretek között egy egyszerü modellel elemezve a következő kérdésekre keressük a választ. Mivel magyarázható, hogy kormánypárti dominancia esetén általában megnő a járadékteremtés, ezzel együtt pedig az állam gazdasági szerepvállalása? Létezik-e a járadékoknak az elit szempontjából optimális szintje? Milyen járadékpolitika segítheti hozzá az elitet a rendszer hosszú távú fenntartásához? Összefügg-e, és ha igen, hogyan az elit járadékpolitikája a demokratikus rendszerek autokráciákhoz való közeledésével? Végül: mit mondhatunk az általunk áldemokráciának nevezett rendszer hosszú távú kilátásairól és fenntarthatóságáról?

Először bemutatjuk azokat a legfontosabb fogalmakat és összefüggéseket, amelyek a további elemzésben kulcsszerepet játszanak. Majd egy egyszerủ modell segítségével kapcsolatot teremtünk a gazdasági szerkezet, a járadékteremtés, valamint a hatalom megszerzésének, illetve megtartásának célja között. Ezt követően a demokrácia lehetséges átalakulását vizsgáljuk egy olyan rendszerré, amely a demokratikus és az autokratikus berendezkedés között helyezkedik el, mindkettő jellegzetességeit 
egyszerre viseli magán, és amelyet éppen ezért áldemokráciának hívunk. E rendszer rövid és hosszú távú müködési sajátosságait is körüljárjuk, a kialakulástól kezdve az esetleges bukásig, majd korábbi eredményeinket illusztrálandó röviden bemutatjuk néhány olyan ország példáját, amellyel kapcsolatban alkalmazhatónak tủnik az áldemokrácia fogalma. A tanulmány rövid összefoglalással zárul.

\section{Alapösszefüggések}

Tanulmányunk a járadékok politikai rendszerekre gyakorolt hatásait vizsgálja demokratikus körülmények között (szabad választásokat feltételezve), különös figyelmet szentelve azoknak az ösztönzőknek, illetve kényszereknek, amelyek elösegítik, vagy épp akadályozzák a demokráciák autoriter rendszerekhez való közeledését. Egyik alapvető fogalmunk a járadék. A közgazdaságtanban a (gazdasági) járadékot abból származtatják, hogy valaki (például az állam) vagy valami (például egy természetes korlát) akadályozza az adott piacra való szabad belépést. A járadék fogalmába beleértjük minden olyan erőforrás piacának korlátozását, amely akár társadalmi, akár politikai, akár más szempontból fontos vagy értékes a szereplők számára. Ez a megközelítés egybeesik North és szerzőtársai [2009] értelmezésével, melynek segítségével a szerzők a természetes állam (idetartozik minden autoriter rendszer) és a nyílt hozzáférésü rend (ide pedig a demokráciák) működési mechanizmusait jellemzik. A politikai rendszerek elnevezésével és besorolásával kapcsolatban nem vállalkozunk arra, hogy mélyreható elemzést nyújtsunk, inkább csupán a leglényegesebb jellegzetességek kiemelésére szorítkozunk. Ennek megfelelően kezdetben mindössze két típust különítünk el: a demokráciát és az autokráciát. A továbbiakban szinonimaként használjuk a demokrácia és a demokratikus rendszer, valamint az autokrácia, az autokratikus és az autoriter rendszer kifejezéseket. Jóllehet ezek az elnevezések az irodalomban nem mindenhol jelentik ugyanazt, témánk szempontjából összevonásuk remélhetően nem okoz zavart.

A politika a hatalomról szól. Beszéljünk akár demokráciáról, akár autokráciáról, a politikusok és a politikai pártok fö célja a hatalom megszerzése, illetve a már hatalmon lévőknek a hatalom megtartása. A szabályok (intézmények) adta kereteken belül olyan stratégiát választanak, amely leginkább hozzásegíti őket céljuk eléréséhez. Ennek érdekében maguk mögé kell állítaniuk az adott rendszer szempontjából legfontosabb szereplőket, csoportokat. Ez a szavazókat, valamint az őket leginkább befolyásolni képes, véleményformáló szereplőket és intézményeket (Downs [1990]), az elit kulcsfiguráit, illetve a mögöttük álló támogatói csoportokat, azaz a klientúrát jelenti.

A klientúra arra a politikai kapcsolatokban megjelenő sajátos struktúrára utal, amelyben a politikusok (patrónusok) hasznokat és előnyöket nyújtanak azon szereplők (kliensek) számára, akik őket támogatják (demokratikus rendszerekben rájuk adják szavazatukat). A hasznok jelenthetnek pénzügyi, pozíciós (kizárólagos vagy

\footnotetext{
${ }^{1}$ Natural state vagy más néven: limited access order, illetve open access order.
} 
preferenciális hozzáférés bizonyos forrásokhoz), eljárási vagy bármilyen más előnyt, és fontos jellemzőjük, hogy nem mindenki részesül belőlük, csak azok, akik az adott csoportot (pártot) támogatták. A támogatás megvalósulását természetesen ellenőrizni is kell, hiszen időben elkülönül a tranzakció két oldala. Mivel a kötelékek általában hosszabb távra szólnak (intézményesülnek), a klientúrarendszer legtöbbször stabil támogatói hátteret nyújt a párt számára, amely nemcsak rövid, de hosszabb távú elkötelezettséget és lojalitást is magában foglal.

Számos országban a politikai kapcsolatok a pártok és a választók között döntően ehhez hasonló személyes, patrónus-kliens viszonyok alapján müködnek, szelektív ösztönzők segítségével, míg a szavazók szavazataikért cserébe klub-, illetve magánjószágokat kapnak (Kitschelt-Wilkinson [2007] 11. o.). Máshol a kapcsolatok a politikusok és a szavazók között jóval személy telenebbek, kollektív ösztönzők irányítják a döntéseket, szigorú monitoringrendszer híján pedig a szavazók szavazatuktól függetlenül részesedhetnek a különböző politikai rendszerek hasznából és költségeiből. Ennek megfelelően különbséget tehetünk a döntően klientúra, illetve az elsősorban programok szerint szervezödő politikai rendszerek között (Scheiner [2006] 15. o.).

Különbség mutatkozik ugyanakkor autokratikus és demokratikus rendszerek között a klientúra és a járadékok szerepe tekintetében. Autokráciákban, ahol a hatalom egy szűk csoport, az elit kezében van, a vezető csoport (koalíció) a hatalmát az értékes erőforrásokhoz való hozzáférés korlátozásából származó járadékokkal tartja fenn. Ezek segítségével képes olyan egyensúlyi helyzetet teremteni, amelynek következtében az eliten belül egyetlen csoportnak sem áll érdekében a hatalom erőszakos megragadása, tiszteletben tartják egymás járadékait, hatalmi törekvéseiket pedig a járadékok megfelelö elosztásával kiépített klientúra mozdítja elő (North és szerzőtársai [2009], Brough-Kimenyi [1986]). Az elit tagjainak fö célja itt tehát kettős: egyrészt az elit hatalmának fenntartása a társadalom többi szereplöjével szemben, másrészt a lehető legjobb pozíció megszerzése az eliten belül.

Hasonló jelenségek számos demokratikus rendszerben is megfigyelhetők, azzal a különbséggel, hogy az eliten belüli versenyt itt a pártok közötti verseny helyettesíti, a klientúra pedig nem elsősorban az eliten belüli hatalmi helyzet erösítését, hanem a választásokon való sikeres szereplés elösegítését szolgálja, mégpedig a pártra leadott szavazatokért cserébe szelektív politika, célzott támogatások és egyéb előnyök nyújtása révén. Ugyancsak fontos különbséget jelent az autokráciákhoz képest, hogy az ott említett két cél közül az első demokráciákban nem játszik szerepet: a rendszer fenntartása és müködtetése ugyanis intézményesített szabályok szerint zajlik, nem pedig erőszak segítségével.

A fő különbség tehát az autokráciák és a demokráciák között a járadékok felhasználása szempontjából az, hogy míg az előbbiekben fóképp az eliten belüli egyensúly megteremtését szolgálja a járadékok felhasználása, addig az utóbbiakban elsősorban a választási esélyek javítását. Jól működő demokráciák esetében a járadékszerzés és a klientúraképzés ráadásul megmarad a demokratikus intézményrendszer keretei között, miközben autokráciákban magában foglalja olyan szereplők és intézmények ellenőrzését is, mint a hadsereg vagy a rendőrség. Erre nyilvánvalóan azért van szükség, mert a rendszer csak eröszakos eszközökkel tartható fenn, így az eröszakszervek 
vezetőinek maguknak is az elit részéhez kell tartozniuk. Végeredményben pontosan ezek azok a követelmények, amelyek miatt autoriter rendszerekben a járadékok egyensúlyi szintje általában jóval magasabb, mint demokráciákban. ${ }^{2}$

A befolyás és a hatalom elengedhetetlen kelléke tehát a járadék, amelyhez a szereplők a piacok és az értékes erőforrásokhoz való hozzáférés korlátozásával jutnak. Minél több járadékra tesznek szert, annál tágabbá válik mozgásterük, annál előnyösebb helyzetbe kerülnek politikai vetélytársaikkal szemben, annál szélesebb klientúrát képesek fenntartani, és annál nagyobb eséllyel szerzik vagy őrzik meg a hatalmat. A járadékszerzésnek vannak azonban költségei is, amelyek legtöbbször nem teszik érdekeltté a szereplőket abban, hogy egy adott járadékmennyiségnél többet vonjanak ki a gazdaságból. A járadékteremtés ugyanis a verseny és a kibocsátás csökkenésével, jóléti veszteséggel is jár, ami növeli a társadalmi elégedetlenséget. Demokráciák esetében a költséget a pártok számára a hatalomért vívott versenyben végső soron a szavazatok elvesztése jelenti. Minél több szavazó pártol el tőlük, annál rosszabb helyzetbe kerülnek, annál kevésbé valószínü, hogy hatalomhoz jutnak (vagy sikerül megtartaniuk azt). Ennek megfelelöen programjaikat, döntéseiket és egész stratégiájukat úgy kell megválasztaniuk, hogy egyszerre vegyék figyelembe a járadékszerzés hasznait és költségeit.

Más a helyzet autokratikus rendszerekben, ahol a járadékteremtés kedvezötlen gazdasági (és jóléti) hatásai nem közvetlen költségként - szavazatvesztés formájában - jelentkeznek, hanem közvetett módon: fokozódik az elégedetlenség az eliten kívüli népesség körében, ${ }^{3}$ illetve emelkednek az ennek kordában tartásához szükséges költségek. Itt az elitnek tehát a járadékok emelkedéséből származó pótlólagos hasznot a társadalmi rend megőrzéséhez szükséges költségnövekedéssel kell összevetnie, amely azonban rendszerint lényegesen kisebb, mint a szavazatvesztéssel járó költségek növekedése demokráciákban. Ennek megfelelően autokráciákban a járadékszerzésből származó veszteség jóval kevésbé korlátozza az elitet, így a járadékok egyensúlyi szintje is sokkal magasabb lesz, hozzájárulva ahhoz az affinitáshoz, amely egyfelől a kizsákmányoló, másfelől a befogadó politikai és gazdasági intézmények (extracting institutions, inclusive institutions) között figyelhetö meg (Acemoglu-Robinson [2013] 76. o.).

A következőkben egy olyan modellt építünk fel, amelyben a demokratikusan megválasztott kormány tetszése szerint módosíthatja a gazdaságban a versenyzői és a monopolista szektor egymáshoz viszonyított arányát, alakítva ezzel a felhasználható járadékok mennyiségét. A járadékok elsősorban pótlólagos szavazatok szerzésére szolgálnak, ám ha erre nincs már többé szükség, a hatalmon lévő párt akár klientúrája

\footnotetext{
${ }^{2}$ Lásd erre vonatkozóan North és szerzőtársai [2009] érvelését. Ugyanakkor az sem meglepő, hogy az eliten belüli versengés csökkentése érdekében az autokratikus rezsimek legtöbbször erősen centralizáltak. A központosított és erős állam így könnyebben tud forrásokat elvonni a gazdasági és társadalmi szereplőktől, de hatékonyabb a járadékok alacsonyabb szintű vezetők és káderek részére történő elosztásában is (Hess [2013] 213. o.).

${ }^{3}$ Az eliten kívülről érkező veszélyt látszólag csökkenti az a jelenség, hogy az olyan államokban, ahol az elit elsősorban nem adók, hanem járadékok segítségével tartja fenn privilegizált helyzetét, sokkal kisebb az igény a társadalom részéről az elit ellenőrzésére, hiszen tagjainak nem kell túlzott mértékű adót fizetniük (Taylor [2011] 299. o.).
} 
szélesítésére, vagy más - rendszerint hosszú távú - előny megszerzésére is felhasználhatja. A monopolszektor növekedésével párhuzamosan ugyanakkor a reálkibocsátás csökken, ami politikai költséggel - szavazatok elvesztésével - jár.

Megvizsgáljuk, hogy a járadékteremtés haszna és költségei milyen stratégiák megvalósítására ösztönzik a kormányzatot, illetve speciális esetben (valódi politikai verseny híján) milyen lehetőségeket nyitnak meg a rendszer esetleges megváltoztatásához. Megközelítésünk különbözik többek között Acemoglu-Robinson [2005] nem demokratikus rendszerek működését leíró modelljétől, Desai-OlofsgardYousef [2009] játékelméleti modelljétől, amely szintén az uralkodó és a többi szereplő közötti kapcsolat szempontjából elemzi az autokratikus hatalom szerkezetét, de Gandhi [2008], valamint Gandhi-Przeworski [2006] modelljeitől is. A fö különbséget az jelenti, hogy míg az előbbiekben felsorolt modellek az elit és a társadalom többi részének viszonyát a hatalom szempontjából vizsgálják, és a szereplők stratégiai interakciói révén megvalósuló egyensúlyi megoldásokat keresik, addig mi a demokrácia stabilitását, valamint az autokrácia irányába történő esetleges elmozdulását a járadékok szempontjából elemezzük.

\section{A modell}

Tekintsünk egy olyan lineáris keresleti függvénnyel rendelkező kétszektoros gazdaságot, ahol az egyik szektor tökéletesen versenyzői, egységnyi határköltséggel és árszínvonallal, a másik szektor pedig monopólium, ugyancsak egységnyi határköltséggel, feleakkora kibocsátással, de magasabb árral. Az 1. ábra mutatja be a két szélső helyzetet, amikor csak verseny vagy csak monopólium van jelen a gazdaságban. A kormányzat szabadon dönthet, hogy a gazdaság mekkora részében legyen verseny $(1-i, 0 \leq i \leq 1)$, és mekkora részt uraljon a monopólium. Feltételezzük, hogy az átalakítás költségmentes. Az ábra tanúsága szerint a reálkibocsátás tökéletes verseny esetén egységnyi, tiszta monopólium esetén $1 / 2$, a nominális kibocsátás 1 és $1 / 2+\beta$, az árszínvonal pedig 1 , illetve $1+2 \beta$. Amennyiben $\beta>1 / 2$, a járadéknövekedés nagyobb, mint a reáljövedelem-csökkenés, azaz ilyenkor nő a nominális jövedelem. Ha viszont $\beta<1 / 2$, a jövedelem abszolút értékben is visszaesik. Ezt elkerülendö a továbbiakban feltételezzük, hogy $\beta>1 / 2$.

Ha a gazdaságban a monopolszektor aránya $i$, a reáljövedelem $Y=1-i / 2$, a nominális jövedelem pedig $Y_{\text {nom }}=\beta i+1-i / 2$. A monopolista szektor profitot (járadékot) realizál, amelynek nagysága $\beta i$. Az árszínvonal alakulását a gazdaságban a deflátorral (D) fejezhetjük ki, amely a nominális és a reáljövedelem hányadosa:

$D=\frac{Y_{\text {nom }}}{Y}=\frac{\beta i+1-i / 2}{1-i / 2}$.

Feltételezzük továbbá, hogy minden függvény az értelmezési tartományán belül kétszer folytonosan differenciálható. A struktúra átalakításának célja a modellben a járadékszerzés, amit a kormányzat az állami tulajdonú monopolszektor méretének növelésével valósíthat meg. Az állami szektor összes profitját nominális 
1. ábra

A versenyzői $(i=0)$ és a monopolizált $(i=1)$ gazdaság összehasonlítása

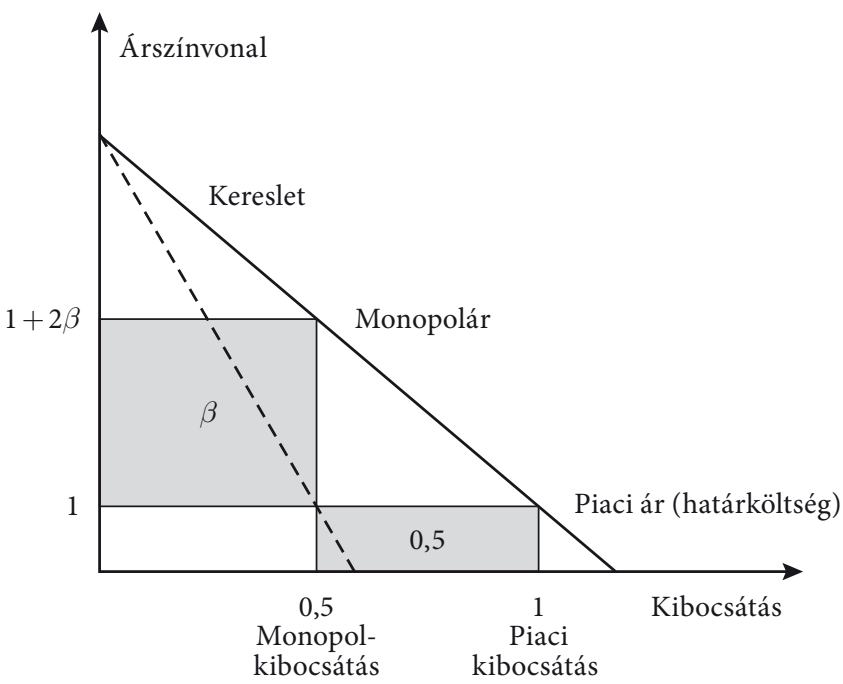

járadéknak, a járadékok reálértékét reáljáradéknak $(R R)$ nevezzük. A járadékgörbét - azaz a reáljáradékot $i$ függvényében - úgy kapjuk meg, hogy a nominális járadékot osztjuk a deflátorral:

$R R(i)=\frac{\beta i(1-i / 2)}{\beta i+1-i / 2}$.

A határjáradék $(M R)$ a reáljáradék $i$ szerinti deriváltja lesz, végül a reáljáradék ott éri el maximumát, ahol $M R$ nulla. Ezt a helyet a 2. ábrán $i_{\max }$-szal jelöljük, a hozzá tartozó értéket pedig járadékmaximumnak $\left(R R_{\max }\right)$ nevezzük. ${ }^{4}$

Demokratikus rendszerekben a kormányzat végső célja a választások megnyerése, amihez a szavazatok többségének megszerzésén keresztül vezet az út. Az egyszerüség kedvéért modellünkben feltételezzük, hogy a hatalomért csak két csoport: a kormányzat és az ellenzék verseng, és az nyeri meg a választásokat, aki több szavazatot szerez.

Legyen a megszerezhető szavazatok összmennyisége egységnyi! Tegyük fel, hogy már nincs messze a választás, és a kormánynak van még egy egyszeri lehetősége a gazdasági szerkezet átalakítására, hogy a rá adott szavazatokat tovább növelje (jól ismert jelenség, hogy a választások évében a kormányzat költségvetési kiadásai - pontosan ettől a céltól vezérelve - általában megnőnek). A monopólium részarányának növelésével $\left(i_{\max }-\mathrm{ig}\right) \mathrm{a}$

$$
{ }^{4} \text { Mivel a határjáradékot az } M R=\frac{\beta\left[(1-i / 2)^{2}-1 / 2 b i^{2}\right]}{[1+(\beta-1 / 2) i]^{2}} \text { összefüggés adja meg, } M R \text { előjele attól }
$$

függ, hogy $(1-i / 2)^{2}-1 / 2 b i^{2}$ pozitív, negatív vagy nulla. Ha $i<2 /(1+\sqrt{2 \beta})$, a határjáradék pozitív, $i=2 /(1+\sqrt{2 \beta})$ esetében nulla, ha pedig $i$ ennél nagyobb, negatív értéket vesz fel. A reáljáradék ott éri el maximumát, ahol a határjáradék nulla. A görbe akkor lesz „visszahajló” (azaz $i_{\max }<1$ ), ha $\beta>1 / 2$ (mint ahogy azt feltételezzük is). Ha $M R$-t ismételten deriváljuk $i$ szerint, az is kiderül, hogy a reáljáradék növekvő szakaszán a határjáradék csökken, azaz a járadékgörbe ezen a szakaszon konkáv. 
2. ábra

A járadékgörbe és a határjáradék

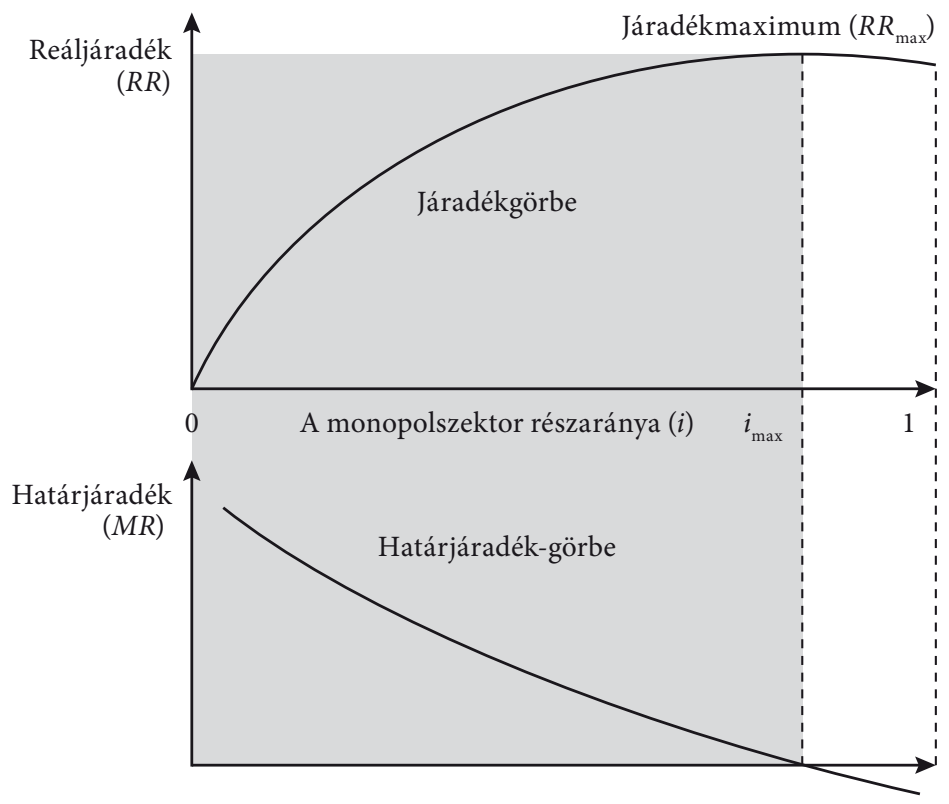

kormány járadékra tesz szert, amelyet a szavazók befolyásolására használhat fel. Minél több forrás áll a rendelkezésére, annál több szavazót tud megnyerni, akár klientúrája kiszélesítése és megerősítése, akár különböző kampányok finanszírozása, akár a média, a sajtó vagy más eszközök felhasználása segítségével.

Az egyszerüség kedvéért feltételezzük, hogy a járadékok révén megnyerhető pluszszavazatok száma, vagyis a szavazatszerzés $(W)$ megegyezik a reáljáradékkal, azaz: $W=R R$. Kikötjük ugyanakkor azt is, hogy a járadékok növelése révén szerezhetö pluszszavazatok száma ne legyen túl nagy, ne fordulhasson elő például, hogy a kormányzat pusztán ezekkel eléri az abszolút többséget, azaz: $R R_{\max }<0,5{ }^{5} \mathrm{~A}$ monopolszektor növekedése ugyanakkor költségekkel is jár. Minél nagyobb a részaránya, annál kisebb lesz a reáljövedelem, ami a népesség körében fokozza az elégedetlenséget, a pártnak pedig szavazatveszteséget okoz. A szavazatveszteséget $(L)$ ennélfogva szintén $i$ növekvő függvényeként értelmezzük, ám a reáljáradékkal (vagyis a szavazatszerzéssel) ellentétben feltételezzük, hogy $i$ növekedésével együtt a pótlólagos szavazatveszteség nő. ${ }^{6}$ Feltételezzük továbbá, hogy $i=0$ esetén a kezdeti átalakítás mindig megéri a kormányzatnak, valamint azt is, hogy $i=i_{\max }$ esetén a szavazatveszteség nagyobb, mint a szavazatszerzés, söt, $L\left(i_{\max }\right)>0,5 .^{7}$

\footnotetext{
${ }^{5} \mathrm{Ez} \beta$-ra vonatkozóan azt jelenti, hogy: $\beta<2,92$.

${ }^{6}$ Ezt alátámaszthatja az a megfigyelés, hogy $i$ növelésével egyidejüleg a reáljövedelem relatív visszaesése egyre nagyobb lesz, ami az elégedetlenség fokozódó mértékủ növekedését vonja maga után.

${ }^{7}$ Feltevéseinket a következőképpen foglalhatjuk össze: $W^{\prime}(i)>0, W^{\prime \prime}(i)<0, L^{\prime}(i)>0, L^{\prime \prime}(i)>0$ minden $i$-re $\left(0<i<i_{\max }\right), W^{\prime}(i)>L^{\prime}(i)$, ha $i=0$, valamint $W^{\prime}(i)=0$ és $L(i)>W(i)$, ha $i=i_{\max }$. $W^{\prime}(i)$ és $W^{\prime \prime}(i)$, valamint $L^{\prime}(i)$ és $L^{\prime \prime}(i)$ a $W(i)$ és $L(i)$ függvények $i$ szerinti első és második deriváltját jelenti.
} 
Nevezzük a kormánypárti szavazatok számát $i=0$ mellett (azaz amikor a gazdaság egésze versenyző) alaptámogatottságnak, és jelöljük $V_{0}$-lal $\left(0<V_{0}<1\right) .{ }^{8}$ Hogyan függ a szavazatszerzés és a szavazatvesztés $V_{0}$-tól? Arra számítunk, minél nagyobb $V_{0}$, minél több embert sikerült már korábban megnyerni, annál nehezebbé (drágábbá) válik további szavazatok szerzése. Másképpen ezt úgy is megfogalmazhatjuk, hogy minél nagyobb az ellenzéki szavazók száma $\left(1-V_{0}\right)$, annál hatásosabb a szavazatszerzés. Az alaptámogatottság a szavazatvesztésre is hatással van. Minél magasabb az alaptámogatottság, annál nagyobb azoknak a száma, akiket potenciálisan elidegeníthet a kormányzati beavatkozás, így azt feltételezzük, hogy az elvesztett szavazatok száma $V_{0}$ emelkedésével együtt nő. Az egyszerűség kedvéért a különböző alaptámogatottságok melletti (feltételes) szavazatszerzést az ellenzéki szavazók számával $\left(1-V_{0}\right)$, a szavazatvesztést pedig a kormánypárti szavazók számával $\left(V_{0}\right)$ tekintjük egyenesen arányosnak. Definiáljuk ezek után a feltételes szavazatszerzést ( $w$ ) és a feltételes szavazatvesztést ( $l$ ) a következőképpen:

$w\left(i, V_{0}\right)=\left(1-V_{0}\right) W(i)$,

$l\left(i, V_{0}\right)=V_{0} L(i){ }^{9}$

Legyen a kormánypárti szavazatok aktuális száma $V(0<V<1)$, a monopolszektor éppen aktuális részaránya pedig $j(0 \leq j \leq 1)$ ! Első közelítésben feltételezésünk szerint a kormányzat a szavazatok maximalizálásában érdekelt, ennek megfelelöen a $V_{0}$ alaptámogatottság melletti hasznossági függvényét a következőképpen definiáljuk:

$u\left(i \mid V_{0}\right)=V_{0}+w\left(i, V_{0}\right)-l\left(i ; V_{0}\right)$.

A felsorolt feltételeknek eleget tevő függvények, valamint $V$ és $j$ alapján kell tehát a kormányzatnak meghatároznia a monopóliumok optimális szintjét $\left(i_{\text {opt }}\right)$, amelynél a feltételes szavazatnyereség maximális. Ha a kormánypárt ismerné alaptámogatottságát $\left(V_{0}-\mathrm{t}\right)$, feladata egyszerü volna, a probléma azonban az, hogy a kormányzat nem $V_{0}$-t ismeri, hanem $V$-t. Ám ez sem jelent gondot, mivel $V$ minden adott $i$-re szigorúan monoton növekvő függvénye $V_{0}$-nak, ${ }^{10}$ így $V_{0}$ egyértelmüen meghatározható $V$-ből és $j$-ből, ennek megfelelően a kormányzatnak a következő feladatot kell megoldania:

$\max _{i} V_{0}+\left(1-V_{0}\right) W(i)-V_{0} L(i)$.

Mivel 0 és $i_{\max }$ között mind $W(i)$, mind $L(i)$ növekvő, $W(i)$ konkáv, $L(i)$ pedig konvex, valamint figyelembe véve korábbi feltételeinket, az egyetlen megoldást a (7) összefüggés szolgáltatja:

\footnotetext{
${ }^{8}$ A két szélső értéket kizárjuk (többek között azért, mert a kormányon lévő párt és az ellenzék vezetői nyilván ellentétesen szavaznak).

${ }^{9}$ Természetes módon terjeszthetjük ki korábbi feltételeinket a fenti kétváltozós függvényekre is, azaz megköveteljük, hogy a kezdeti átalakítás minden $V_{0}$ esetén pótlólagos szavazatokat hozzon a kormánypártnak: $\partial w / \partial i>\partial l / \partial i$, minden $V_{0}$-ra, ha $i=0$. Ebböl azonban következik, hogy ha $V_{0}$ tart az 1-hez, a $w / \partial i=\left(1-V_{0}\right) W^{\prime}(i)$ kifejezés bármilyen kis értéket felvehet, ami azonban $\partial l / \partial i=V_{0} L^{\prime}(i)$ miatt azt jelenti, hogy $L^{\prime}(i)$ nem lehet pozitív, csak nulla. Így tehát: $L^{\prime}(i)=0$, ha $i=0$.

${ }^{10}$ Minden adott $i$-re $\left(0 \leq i \leq i_{\max }\right)$ az aktuális szavazatok száma megegyezik az alaptámogatottság és a feltételes szavazatnyereség összegével: $V=V_{0}+w\left(i, V_{0}\right)-l\left(i, V_{0}\right)$. Ezt a kifejezést a $V=V_{0}\{1-W(i)-L(i)\}+$ $+W(i)$ alakra írhatjuk át. Figyelembe véve továbbá, hogy $W(i)-L(i)<1$, megkapjuk a kívánt összefüggést.
} 
$\left(1-V_{0}\right) W^{\prime}(i)=V_{0} L^{\prime}(i)$.

Ezt a helyet a $V_{0}$ alaptámogatottság melletti optimumhelynek nevezzük, és $i_{\mathrm{opt}}$-tal jelöljük (lásd 3. ábra). ${ }^{11}$ A pluszszavazatok száma ekkor $V_{\mathrm{opt}}=w\left(i_{\mathrm{opt}}, V_{0}\right)-l\left(i_{\mathrm{opt}}, V_{0}\right)$ a szavazatoptimum lesz, a kormány által megszerezhetó összes szavazat pedig $V_{\max }=V_{0}+V_{\text {opt }}$ a szavazatmaximum lesz. A kormány akkor dönt optimálisan, ha az állami szektor arányát az eredeti $j$ helyett $i_{\mathrm{opt}}$-ra módosítja. Minden $V_{0}$ alaptámogatottsághoz tartozik tehát pontosan egy olyan $i$ érték $\left(i_{\text {opt }}\right)$, amely megmutatja, mekkora legyen a monopolszektor részaránya a gazdaságban a szavazatok maximalizálása érdekében. A (7) összefüggésből látható, hogy ha $V_{0}$ emelkedik, $W^{\prime}(i)$-nek nőnie, míg $L^{\prime}(i)$-nek csökkennie kell az egyenlőség fenntartása érdekében. Minthogy azonban $W^{\prime}(i)$ csökkenö, $L^{\prime}(i)$ viszont növekvö, az egyensúly csak $i_{\text {opt }}$ csökkentésével tarható fenn. Ahogy $V_{0}$ a nullához tart, úgy közelít $i_{\text {opt }}$ az $i_{\max }$-hoz, míg ha $V_{0}$ az 1-hez, $i_{\text {opt }}$ a nullához tart. Minél nagyobb tehát az alaptámogatottság, annál kisebb méretü monopolszektor szükséges a szavazatok maximalizálásához. Ez azért van így, mert magas alaptámogatottság mellett a pótlólagos szavazatveszteség $\left(V_{0} L^{\prime}\right)$ már nagyon alacsony $i$ mellett eléri a pótlólagos szavazatokból származó nyereséget: $\left(1-V_{0}\right) W^{\prime}$. Az $i_{\text {opt }}\left(V_{0}\right)$ függvény alakját a 4 . ábra mutatja $\beta=1$ érték mellett. Összefoglalva az eddigieket: a kezdeti feltételek ( $V$ és $j$ ) egyértelmüen meghatározzák a kormányzat stratégiáját, amelynek segítségével legfeljebb $V_{\max }=V_{0}+V_{\text {opt }}$ számú szavazatot érhet el.

\section{3. ábra}

Szavazatszerzés és szavazatvesztés $i$ függvényében $\left[V_{0}=0,6, \beta=1\right.$ és $\left.L(i)=i^{2}\right]$

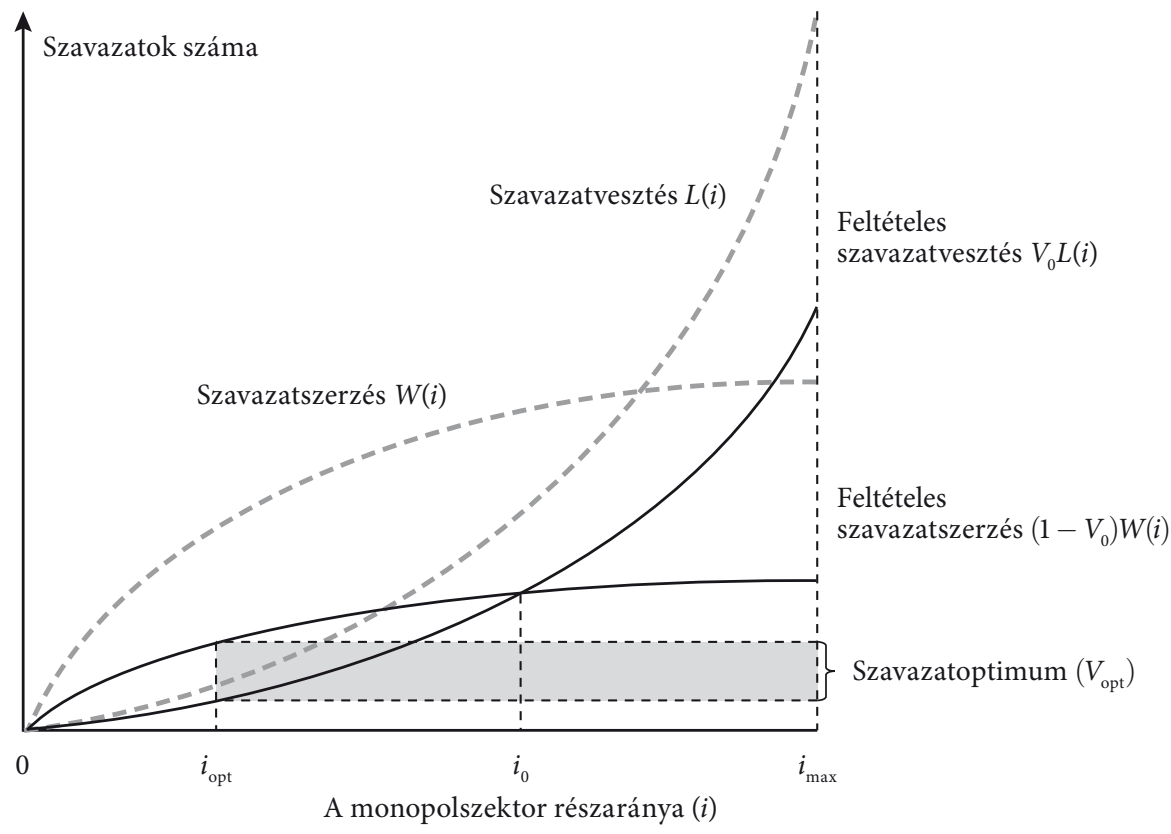

${ }^{11}$ A feleslegesen bonyolult $V_{\text {opt }}^{V_{0}}$ jelölés helyett. 
A modell szerint a gazdasági szerkezet átalakítása pótlólagos szavazatokat hozhat a kormányzat számára, ami hozzájárulhat a választási győzelem kivívásához. A választási győzelemhez azonban elegendő 50 százalék plusz egy szavazat is, az efölötti szavazatok hozadéka a hatalomra kerülés szempontjából nulla. Jóllehet a bizonytalanság csökkentése, valamint a nagyobb arányú győzelemmel járó előnyök ösztönözhetik a kormánypártot a szavazatok 0,5 fölé tornászására, a következőkben azt az esetet fogjuk megvizsgálni, amikor a cél pusztán az egyszerű többség (modellünkben a 0,5-es küszöb) elérése. ${ }^{12}$ A hatalmon lévők számára ugyanakkor a járadékok hasznosak, hiszen másra is felhasználhatók, mint közvetlen szavazatszerzésre, például jelentős forrásokat nyújthatnak hosszabb távú politikai célok megalapozásához. ${ }^{13}$ Emiatt a kormányzat $V_{0}$ melletti hosszú távú hasznossági függvényét a szabadon felhasználható járadékok, azaz a járadéktöbblet mennyiségével definiáljuk:

$u_{h}\left(\alpha, i \mid V_{0}\right)=R R(i)-\alpha R R(i)$.

A (8)-ban $R R(i)$ a reáljáradékok szintjét, $\alpha R R(i)$ pedig a (rövid távú) szavazatszerzésre fordított járadékok mennyiségét jelenti $i$ és $V_{0}$ függvényében $(0 \leq \alpha \leq 1)$. E szerint a járadéktöbblet a közvetlen szavazatszerzésre fel nem használt járadékok mértékét mutatja, az $\alpha$ változó pedig azt fejezi ki, hogy a hatalmon lévők nem feltétlenül használják fel az összes járadékot rövid távú szavazatszerzésre, hanem csak annyit, amennyi éppen elegendő a szavazatok többségének megszerzéséhez. A fennmaradó járadékot így „tartalékolják” más - elsősorban hosszabb távú - célok elérésére reményében. Ezekkel a motivációkkal a következő részben foglalkozunk. Feltesszük természetesen azt is, hogy adott $V_{0}$ esetén csak olyan $\alpha$ és $i$ kombinációk jöhetnek szóba, amelyeknél a kormányzat eléri az abszolút többséget. A feladat ennek megfelelően $V_{0}$ adott értékei mellett a következő:

$\max _{\alpha, i} R R(i)-\alpha R R(i)$,

feltéve hogy

$V_{0}+\alpha\left(1-V_{0}\right) R R(i)-V_{0} L(i) \geq 0,5, \quad \alpha \geq 0 \quad$ és $\quad \alpha \leq 1$.

A feltételes optimalizálási feladat megoldásaként ${ }^{14}$ három különböző lehetőség adódik. Ha $\alpha=1$, azaz a kormányzat az összes járadékot szavazatszerzésre használja fel, egyetlen megoldást kapunk, ott, ahol $V_{0}+\left(1-V_{0}\right) R R(i)-V_{0} L(i)=0,5$ és $\left(1-V_{0}\right) M R(i)=V_{0} L^{\prime}(i)$ egyszerre teljesül. Ez a legkisebb $V_{0}$ érték, amelynél a kormányzat már éppen eléri az abszolút többséget, így ezt $V_{0}^{\min }$-nel jelöljük. Amenynyiben $\alpha=0$, tehát a kormánypárt egyáltalán nem használ járadékot szavazatok szerzésére (mivel az alaptámogatottsága magasabb, mint 0,5), az optimum feltétele: $V_{0}-V_{0} L(i)=0,5$. Ez azt jelenti, hogy addig növeli $i$-t (a monopolszektor részarányát), amíg a támogatottsága 0,5 -re nem csökken. Minthogy azonban itt már $i \geq i_{\text {opt }}$, tovább

\footnotetext{
${ }^{12} 0,5$ helyett minden nehézség nélkül alkalmazható lenne bármilyen más $\xi \geq 0,5$ küszöb is.

${ }^{13}$ Jelentsen ez akár olyan intézkedéseket, amelyek demokratikusak, akár olyanokat, amelyek már a rendszer határait feszegetik.

${ }^{14}$ A feladatot a Kuhn-Tucker-feltételeknek megfelelő alakra hozva, és külön-külön megvizsgálva az $\alpha=0$, az $\alpha=1$ és az $0<\alpha<1$ eseteket.
} 


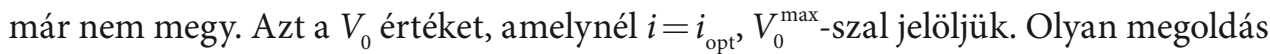
is elképzelhető lenne, amelynél a támogatottság sohasem esik 0,5 alá, azaz 0 és $i_{\max }$ között minden $i$-re $V_{0}-V_{0} L(i)>0,5$. Ezt azonban kizárjuk, mivel korábban feltételeztük, hogy $L\left(i_{\max }\right)>0,5$. Végül, amennyiben $0<\alpha<1$, a járadékokat a kormányzat csak részben használja fel szavazatok szerzésére, az optimumhelyek pedig, amelyeket megint csak a (7) összefüggés határoz meg, egybeesnek az eredeti (nem korlátozott) feladat $i_{\text {opt }}$ helyeivel. A megfelelö $V_{0}$ értékek ilyenkor szükségszerüen $V_{0}^{\min }$ és $V_{0}^{\max }$ közé esnek. A (6) és a (9) feladatok megoldásait, valamint a járadéktöbblet mennyiségét $V_{0}$ függvényében a 4 . ábra mutatja be:

\section{4. ábra}

A monopolszektor optimális szintje és a járadéktöbblet $V_{0}$ függvényében (az $L=i^{2}$ függvénnyel számolva, a $\beta=1$ paraméter mellett)

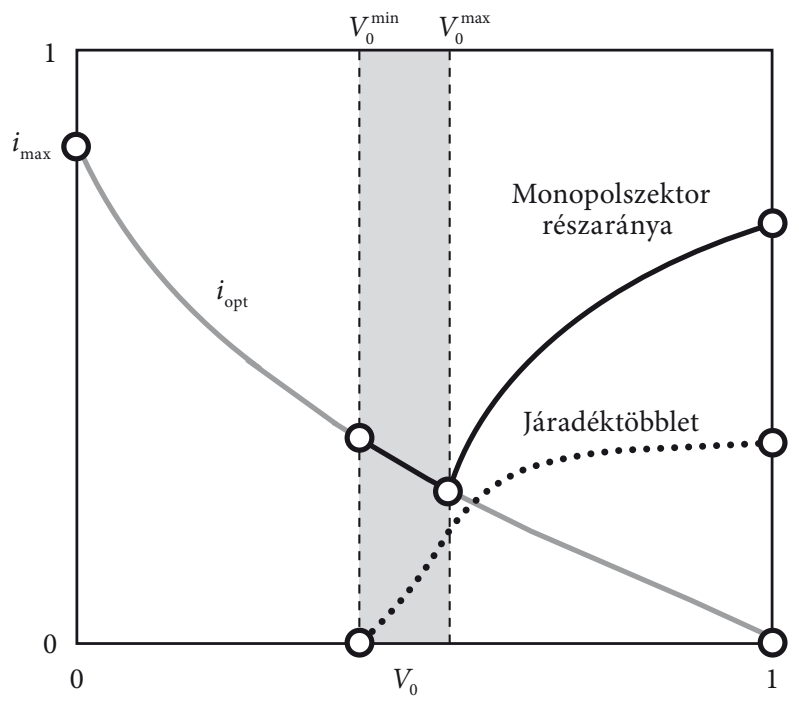

Figyelemreméltó, hogy $V_{0}^{\min }$ és $V_{0}^{\max }$ között az alaptámogatottság növekedése a monopolszektor optimális méretének csökkenésével jár együtt. Ez azért van így, mert nagyobb $V_{0}$-hoz kisebb $i_{\text {opt }}$ tartozik, márpedig $V_{0}^{\min }$ és $V_{0}^{\max }$ között $i>i_{\text {opt }}$ esetén $\mathrm{MR}(i)<L^{\prime}(i)$ adódna, azaz a kormány nemhogy növelni nem tudná a járadéktöbbletet, de még a szavazatveszteséget sem lenne képes pótolni. Ezért itt mindig $i=i_{\text {opt }}$-ot választja. Eközben azonban egyre kevesebb járadékot szükséges szavazatszerzésre fordítania ( $\alpha$ értéke $V_{0}^{\min }$ és $V_{0}^{\max }$ között 1-ről 0-ra csökken), járadéktöbblete pedig emelkedni kezd. Végül, $V_{0}^{\max }$ fölött már egyáltalán nem használ járadékot szavazatszerzésre $(\alpha=0)$, hanem addig növeli $i$-t, amíg a szavazatai $V_{0}$-ról 0,5-re csökkennek. Ebben a pontban ugyanis már $M R(i)<L^{\prime}(i)$, ami nem teszi érdekeltté további monopolizációban.

Az optimális stratégia alakulása $V_{0}$ függvényében számos érdekes megállapításra ad lehetőséget. Mindenekelőtt jól látható, hogy a küszöbérték (jelen esetben 0,5) közelében a legnagyobb a versenyzői szektor részaránya, ami általában magasabb kibocsátást 
és hatékonyabb termelést jelent. Eszerint az éles politikai verseny jótékony hatással van a gazdasági teljesítményre, még akkor is, ha a többletjáradék mértéke ezen a szakaszon gyorsan emelkedik, hiszen társadalmi szempontból nincs nagy különbség aközött, hogy most vásárol-e szavazatokat a kormány, vagy később. Ahogy azonban a kormányzat támogatottsága tovább emelkedik, a korábbi stratégia gyökeres fordulatot vesz, és $V_{0}^{\max }$ fölött a monopolizáció gyors ütemü növekedésnek indul. A 4. ábrán jól látható, hogyan éri el a monopolszektor részaránya $V_{0}=0,6$-nél a 40 , majd pedig $V_{0}=0,67$-nél az 50 százalékot (ismét csak az $L=i^{2}$ függvénnyel, $\beta=1$ paraméter mellett). Mindez felveti annak a lehetőségét, hogy egy domináns pozícióban lévő kormánypárt a monopolszektor kiterjesztésével jelentős járadéktöbbletre tesz szert, amelyet végül saját pozíciójának bebetonozására, klientúrája elmélyítésére, a demokratikus keretek feszegetésére vagy az ellenzék visszaszorítása használ fel. Hogy ennek az elvi lehetőségnek melyek a motivációi és feltételei, a következőkben vizsgáljuk meg.

\section{Áldemokráciák}

Ebben a részben egy olyan politikai rendszert vizsgálunk, amely már nem valódi demokrácia, de még nem is autokrácia. Olyan rendszer, amely mindkét említett típus jegyeit magán viseli, ugyanakkor sok tekintetben különbözik is tőlük. Fő kérdésünk a következő: eljuthat-e, sőt el akar-e jutni egyáltalán egy ország a versenyen alapuló demokratikus piacgazdaságtól a monopolizált piacok járadékteremtésétől függő autokráciáig - és ha igen, hogyan, milyen feltételek mellett lehet erre képes? Bár a politikusok demokráciában is arra törekednek, hogy megszerezzék, megtartsák és lehetőség szerint növeljék hatalmukat, a jól kitalált és jól működő intézményrendszer általában korlátot szab törekvéseiknek. A politikai intézmények itt a szereplöket legtöbbször abban teszik érdekeltté, hogy a keretek által meghatározott lehetőségeken belül keressék boldogulásukat, ne pedig azokon kívül. Az esetleges jutalmak és büntetések (a kifizetések) nem ösztönzik a szereplőket a szabályok felrúgására, a rendszer megváltoztatására és a demokrácia feladására. A jól müködő demokráciákban olyan intézmények alakítják a szereplők mozgásterét és döntéseit, amelyek nem támogatják a dezertőr magatartást, ellenben jutalmazzák a rendszer fenntartása érdekében létrejött kooperációt.

Történelmi példák ugyanakkor arra figyelmeztetnek, hogy nem minden demokrácia bizonyul tartósnak, nem mindig áll a szereplők érdekében a játékszabályok betartása. Minek köszönhető, hogy egyes esetekben a demokratikus rendszer sérülékeny, míg más esetekben nagyon is stabil? Jóllehet a megfelelö intézményi struktúra elengedhetetlen, a szabályok megléte - legyenek bármilyen átgondoltak is - önmagában nem elegendő a hosszú távú stabilitásához. ${ }^{15}$ A hatalmi ágak szétválasztása, a fékek és ellensúlyok rendszere szükséges ugyan a demokrácia megfelelő müködéséhez, de nem elégséges.

\footnotetext{
${ }^{15}$ Abdukadirov [2010] is amellett érvel (369-370. o.), hogy a választások önmagukban nem elégségesek a demokratikus működéshez, sőt akár még erősíthetik is az autoriter rendszereket. A választások ugyanis jelzésként szolgálhatnak az autokratikus elit számára, hogy mely csoportok mennyire hasznosak, melyeket érdemes bevonni a felsőbb vezetésbe, és milyen mértékű járadékátcsoportosítást igényelnek az egyes politikai stratégiák.
} 
Akárcsak Downs [1990], mi is úgy véljük, mindenképpen szükség van megfelelö erővel rendelkező, valóban versengő politikai pártokra (vagy pártkoalíciókra).

Amennyiben egy demokráciában nincs valódi pártverseny, és egyetlen csoport kezében összpontosul a hatalom, a többi párt jelenléte és tevékenysége pedig inkább csak olyan díszlet, amely a politikai életet színesíti, a megszokott ösztönzők (azok költségei és haszna) átalakulnak. Olyan vonzó lehetőségek tárulnak fel, amelyek jól működő demokratikus rendszerekben - ahol valódi verseny folyik a pártok között elképzelhetetlenek. Utóbbiakban ugyanis a gazdasági visszaesést, a hatékonyság csökkenését és a jelentősebb járadékok bizonyos politikai csoportokhoz való áramlását általában nagyon gyorsan megbüntetik a szavazók: a következő választások alkalmával másra adják voksukat. Modellünkben mindezt a kormányzat szavazatszerzési lehetőségeinek viszonylagos szűkösségét mutatja, ami a szavazatvesztés $(L)$ gyors növekedési ütemének tulajdonítható (lásd 3. ábra), és - az autoriter rendszerekhez képest - alacsonyan tartja az állami szektor részarányát. Ameddig a kormánypárt alaptámogatottsága nem haladja meg jelentős mértékben a küszöbértéket (0,5-öt), azaz a kormányzat helyzete bizonytalan, nem áll érdekében túlságosan nagyra növelni a monopolszektort, így tudja ugyanis a legjobb esélyeket megteremteni mind saját újraválasztása, mind jövőbeli lehetőségei érdekében.

Ha azonban $V_{0}$ jelentősen meghaladja $V_{0}^{\max }$-ot, teljesen más helyzet alakul ki. Ekkor ugyanis a győzelemhez szükséges szavazatokon felül nagy mennyiségü tartalékszavazat halmozódik fel, amelyek rövid távú határhaszna közel nulla. Ilyenkor a kormány elgondolkozhat azon, hogy e szavazatok helyett járadékot szerezzen inkább, úgy növelve tovább a monopolszektor részarányát (csökkentve ezáltal a rá érkező szavazatok számát), hogy a hatalom megtartása ne kerüljön veszélybe (a 4. ábrán jól látható ez a jelentős potenciál). A megszerzett járadék lehetővé teszi például, hogy új szavazók toborozása helyett saját szavazói bázisát és klientúráját szélesítse, erősítse és mélyítse ${ }^{16}$ növelve a választók párt iránti hosszú távú elkötelezettségét. Ily módon a többletjáradék mint hatékony eszköz hozzásegítheti a kormányzatot hatalmának hosszú távú fenntartásához. Miközben tehát feladja rövid távú szavazatmaximalizálását egy hosszabb távon kedvezőbb eredményeket kínáló többletjáradék-maximalizáló stratégia kedvéért, újraválasztása továbbra is biztosítva marad.

Olyan demokratikus országokban, ahol a politikai pártok elsősorban programok szerint szerveződnek, mint például Németországban vagy az Egyesült Királyságban (Scheiner [2006], Kitschelt-Wilkinson [2007]), ez a lehetőség kevésbé vonzó, hiszen nincs jelentős hosszú távú következménye annak, ha egy párt erősíti klientúráját, mivel a következő választásokon a szavazatok megoszlását nem ez, hanem mindenekelőtt a programok és a (várt) teljesítmények határozzák meg. Olyan demokratikus országokban azonban, ahol - erős (gyakran személyes) politikus-szavazó kötődésekkel (Scheiner [2006] 94. o.) - a politika alapvetően a klientúrarendszeren keresztül zajlik (mint például Olaszországban, Japánban, Indiában vagy épp Magyarországon), a járadékok klientúraépítésre való felhasználása

\footnotetext{
${ }^{16}$ Minél szélesebb ugyanis a klientúra, annál stabilabb a rendszer (ugyanakkor annál költségesebb is a fenntartása) (Sekeris [2011] 240. o.).
} 
igen jövedelmező hosszú távú befektetés lehet. ${ }^{17}$ Figyelemreméltó, hogy egy párt által dominált demokrácia leggyakrabban olyan országokban alakul ki, ahol a klientúrarendszer meghatározó jelentőségü.

A klientúraépítésen és klientúramélyítésen túl a vezetök természetesen olyan lépéseket is tehetnek, amelyek a gazdasági hatékonyság, a verseny és a jövedelem csökkenése mellett a politikai versengést is csökkentik, mégpedig az értékes eröforrásokhoz való hozzáférés nyílt vagy burkolt korlátozásával. Ilyen lépésekre - melyek eltávolodást jelentenek a demokráciától - végső soron azért kerülhet sor, mert a hatalomban lévők felelősségre vonhatósága és elszámoltathatósága, komoly ellenzéki erő híján, nem igazán müködik. Ezek a folyamatok végül oda vezethetnek, hogy megkérdőjeleződik a politikai rendszer demokratikus jellege. Jóllehet nehezen húzható határvonal ezen országok, valamint az egy párt által uralt, ám hasonló jellegzetességeket nem mutató demokratikus országok közé, előbbieket áldemokratikus országoknak nevezzük. A különbség a két típus között elsősorban a pótlólagos járadékszerzés mértékében, valamint abban a törekvésben lelhetö fel, amelynek során a hatalmon lévők $a$ járadékokat (mindenekelött a demokratikus intézmények és az ellenzék helyzetének meggyengítésével) tartós politikai elönyökké óhajtják transzformálni. Az egypárti dominanciát mutató demokráciák és az áldemokráciák közötti különbség ebből a szempontból nagyon hasonló a közönséges monopólium és a versenykorlátozó magatartást tanúsító monopólium közötti különbséghez, hiszen mindkét esetben maga a tevékenység határozza meg egyfelöl a rendszer jellegét, másfelől a monopóliummal szembeni esetleges fellépés lehetőségét és mértékét.

Végeredményben tehát elmondható, hogy bizonyos körülmények között a demokratikusan megválasztott kormányok - anélkül, hogy formálisan megváltoztatnák a politikai rendszer alapvető elemeit - racionálisan viselkednek, ha túlmennek a rövid távú szavazatoptimumon, és a megszerezhető járadékok segítségével lépéseket tesznek hatalmuk tartósítása és elmélyítése érdekében. E lépésekkel szavazatokat veszítenek ugyan, az elkövetkezendő választásokon azonban (akár több cikluson keresztül is) kedvezőbb helyzetből indulnak immár nem maximális, ám megerösített szavazóbázisuk, valamint az ellenzék visszaszoritása segitségével.

Elvezet-e ez a folyamat végül az autokrácia kialakulásához? Nem feltétlenül, sőt a tapasztalatok fényében csak meglehetősen ritkán. A járadékok növekvő szintje a rendszer tartós megváltoztatásának ugyanis csupán a kezdeti lehetőségét jelenti, a valódi fordulat megvalósításához a kormányon lévő pártnak számos további lépést kell tennie. Meg kell szereznie azokat a politikai és gazdasági hídfóállásokat, amelyek hiányában az autokratikus uralom nem tartható fenn hosszabb ideig. Közülük is a legfontosabb az eröszakszervek feletti ellenőrzés (North és szerzötársai [2009]) a kulcsszereplök megnyerése révén, de nem hanyagolható el sem a közigazgatás, sem pedig a bíráskodás kézben tartása. Gazdasági tekintetben a

\footnotetext{
${ }^{17}$ Tovább erősítheti a hatalmon lévők újraválasztási esélyét az is, ha a költségvetés erősen centralizált, mivel a forrásallokáció központi ellenőrzése következtében a helyi klientúra kiszolgáltatottá válik a központtal szemben. E két elem együttes jelenléte hat igazán ösztönzően mind a helyi politikusok, mind a helyi szavazók számára, hogy a legerősebb (hatalomban lévő) pártot támogassák (Scheiner [2006]).
} 
járadékok megfelelő szintje mellett követelményként a stratégiai jelentőségű vállalatok és iparágak irányítása említhető. Már ebből a rövid felsorolásból is látszik, hogy az autokratikus rendszer kiépítése és a hatalom megszilárdítása igen nehéz, általában hosszú időt igénylő feladat.

De miért kellene a kormányzatnak formálisan is megváltoztatnia a rendszert, ha egyszer olyannyira sikeres, hogy a választásokon nincs igazi vetélytársa? Jelentősen csökkenti az autokrácia bevezetésének vonzerejét az is, hogy az új rendszer kialakítása számos veszéllyel járhat. Előfordulhat, hogy nem sikerül a tervezett átalakítás, ami akár a vezetők karrierjébe (esetleg életébe is) kerülhet. Nem kizárható, hogy az átalakítás során a hatalom más csoportok (például a katonaság, tábornokok) kezébe megy át; vagy éppenséggel az is megtörténhet, hogy a tervezett beavatkozás végül káoszba, polgárháborúba vagy jó esetben „csupán” gazdasági összeomlásba taszítja az országot. Pontosan e veszélyek és nehézségek miatt a kormányzat sokszor még akkor sem vállalja fel az autokratikus rendszer bevezetését, és inkább a demokrácia látszatának fenntartása mellett dönt, ha mind eszközei, mind lehetőségei meglennének ahhoz, hogy autokratikus fordulatot hajtson végre. A demokrácia formális fenntartása ráadásul lehetővé teszi, hogy vereség esetén a volt kormánypárti politikusok belátható időn belül esetleg újra szerepet vállaljanak a hatalomban.

\section{Sajátosságok, kilátások, példák}

Az áldemokráciák lényegében két vonásukban különböznek az autoriter rendszerektől. Egyfelől a politikai intézményrendszer alapvető jellegében (szabad választások és az alapvető demokratikus intézmények megléte, illetve hiánya), másfelől az értékes erőforrásokhoz való hozzáférés korlátozásának mélységében. Bár az első különbség fontosnak látszik, relevanciája csak akkor mutatkozik meg, ha a kormányzó párt hatalma olyannyira erodálódik, hogy szóba kerül egy esetleg a választási vereség is (ekkor azonban már nem beszélhetünk áldemokráciáról). A második különbség ugyanakkor igen fontos. Stabil autokráciákban, ahol a hatalmi viszonyokat a szereplők ereje határozza meg, a rendszer fenntarthatósága érdekében az elitnek szükségszerüen magában kell foglalnia az erőszakszerveket és az állami bürokrácia felső szintjeit, ami magasabb költségekkel jár, és lényegesen nagyobb mennyiségű járadékot igényel.

A demokráciából esetlegesen kialakuló áldemokráciában ezzel szemben a meglévő demokratikus intézményrendszer nem teszi szükségessé az említett területek feletti közvetlen ellenőrzést. A hatalmon lévők ilyen irányú befolyása, valamint az ehhez szükséges járadék - kezdetben legalábbis - vagy hiányzik, vagy jóval csekélyebb mértékű, mint autokráciákban, nem téve általában lehetővé a társadalommal szembeni erőszakos fellépést, egy mindenható állampárt esetleges kiépítését vagy a gazdaság fontosabb hídfőállásainak elfoglalását. Mindehhez idő kell. Hosszabb távon természetesen nem kizárt, hogy az elitnek sikerül megteremtenie az autoriter rendszer politikai és gazdasági alapjait, és lépésről lépésre felszámolva a demokráciát bebetonoznia hatalmát, ám ha ennek hiányában is képes hatalomban maradni, a korábbiakban említett veszélyek miatt nem valószínü, hogy megkísérli ezt. 
Hasonlóság mutatkozik ugyanakkor az áldemokrácia és az autokrácia között, mégpedig abban a vonatkozásban, hogy a járadékok mindkét esetben meghaladják a valódi politikai versenyen alapuló demokráciákban megszokott szintet. Autoriter rendszerekben a járadékok növelésének az eliten belüli versengés szempontjából van nagy jelentősége, míg áldemokráciákban a járadékok megszerzésének legfontosabb célja a saját szavazóbázis - klientúra - megerősítése, valamint más demokratikus erők térnyerésének és a választásokon való sikeres szereplésének megakadályozása. Mindkét esetben - jóllehet eltérő közvetlen célok elérése érdekében - a klientúrarendszer pénzelése és hatalmi hálóba való beépítése jelenti azt a kötőanyagot, amely összetartja mind az elitet, mind magát a rendszert. ${ }^{18}$ Ily módon az áldemokráciák köztes helyet foglalnak el a demokráciák és az autokráciák között, mivel nem rendelkeznek számos olyan eszközzel, amely a valódi autoriter rendszerek fenntartásához elengedhetetlen lenne, működésmódjuk azonban számos ponton autokratikus jegyeket mutat.

Hogyan tekintsünk ezek után az áldemokráciákra? Úgy, mint demokráciákra, amelyekben a politikai rendszer formálisan demokratikus, az elit gazdasági pozíciói és járadékszerzési képessége ugyanakkor jóval nagyobb a megszokottnál, vagy úgy, mint sajátos autokráciákra, amelyekben az elit járadékszerző tevékenysége általában nem éri el az autoriter rendszerekre jellemző (igen magas) szintet, politikailag pedig nem birtokolják azokat az eszközöket, amelyek a hatalom (akár erőszakos) megtartásának feltételeit jelentenék?

Minthogy az áldemokráciák kétarcú képződmények, az előbbiekben bemutatott két nézőpont egyaránt lehetséges, egyaránt védhető. A járadékok felől közelítve azonban inkább a második szemlélet tünik pontosabbnak. Az áldemokráciák gazdasági tekintetben ugyanis nagyon hasonlítanak az autoriter rendszerekhez: jelentős mértékü járadékképzés megy végbe bennük, ami csökkenti a gazdaság teljesítőképességét. Nem véletlen, hogy áldemokráciákban - hasonlóan más autoriter rendszerekhez - nemigen találkozhatunk jól müködő piacgazdaságokkal, ehelyett müködésük alapját sok esetben a járadékszerzést célzó kizsákmányoló intézmények (Acemoglu-Robinson [2013] 76. o.) jelentik, amelyek általában lassabb és torz fejlődést eredményeznek. Az áldemokráciák emiatt leginkább a demokrácia és az autokrácia határán megjelenő köztes formáknak tekinthetők, autokratikus jellegzetességekkel, ám valódi autoriter hatalom nélkül.

Milyen kilátásai vannak a kormányzatnak hatalma megörzése tekintetében, illetve milyen veszélyek és kényszerek okozhatják bukását? Az áldemokráciákra leselkedő legfőbb veszély alapvetően ugyanaz, mint az autoriter rendszerek esetében: a járadékok magas szintje miatt a gazdasági teljesítmény hosszú távon elmarad nemcsak a demokratikus (fejlett) piacgazdaságokétól, de általában az ország saját elvárásaitól is. Miért jelent azonban ekkora problémát az állami monopolszektor magas

${ }^{18}$ A klientúrahálózatok fontossága aligha becsülhető túl. Rigger [1999] arról számol be, hogy míg a demokratikus berendezkedésű országnak számító Japánban a hálózat a legalacsonyabb szintektől a legmagasabb szintig egyfajta vertikális struktúrát mutat, addig Tajvanon (mely egészen a legutóbbi időkig autoriter rendszerként működött) a szerveződés sokkal inkább horizontális jellegű, regionális hangsúlyokkal (85. o.). Érdekes módon Wade [2010] (157. o.) az összes kelet-ázsiai fejlesztő államot (így Japánt is) a korlátozott hozzáférésü rend kategóriájába sorolja. 
részaránya a versenyzőihez képest? Mind történelmi példák, ${ }^{19}$ mind az előző részben bemutatott modell, mind pedig széles körben elfogadott elméletek azt mutatják, hogy a növekedés (modellünkben a kibocsátás) hosszú távon a versenyzői piacokon alapuló demokráciákban várhatóan gyorsabb lesz, mint az állami monopóliumok dominanciája mellett működő autokráciákban.

A magyarázatok igen sokfélék. Hayek [1995] a piacgazdaság jobb teljesítményét az árszabályozó piac és a verseny hatékonyabb információfeldolgozási képességére vezeti vissza, Kornai [2011] az innovációs képesség szempontjából mutatja ki a kapitalista piacgazdaság jelentős fölényét a szocialista tervgazdasággal szemben, Acemoglu-Robinson [2013] a hosszú távú teljesítménybeli különbségeket a befogadó, illetve kizsákmányoló intézmények dominanciájával magyarázza. Mousseau [2012] az autoriter rendszerekben megfigyelhető lassabb növekedés okaként a klientúra fenntartásához szükséges járadékok mértékét, ebből következően pedig a közjavak nyújtásának alacsony szintjét jelöli meg, míg Tullock [1988], valamint Murphyés szerzőtársai [1993] többek között a járadékvadászat jelentős társadalmi költségeiben látja a különbséget. Végül, Brough-Kimenyi [1986] a diktatúrák gyengébb teljesítményét azzal magyarázza, hogy az elit saját klientúráját részben az állami szféra (például az állami vállalatok menedzsmentjének) jól fizető állásaival jutalmazza, ami kontraszelekcióhoz és alacsony hatékonysághoz vezet.

A hosszú távon mutatkozó gyengébb gazdasági teljesítmény előbb-utóbb tehát aláássa a kormányzat domináns pozícióját, $V_{0}$ lassan balra tolódik, megközelíti (és általában el is éri) a felezőpontot, a kormányzat pedig döntési kényszerhelyzetbe kerül. Vagy végrehajtja az autokratikus fordulatot, még mielött forrásai kevésnek bizonyulnának ehhez, vagy az elit tagjai megpróbálják kivételezett helyzetüket hosszú távú (általában gazdasági) előnnyé konvertálni, ha már a politikában élvezett átmeneti monopólium nem tartható tovább fenn. Az autokrácia kiépítésének jelentős költségei miatt az elit általában a második megoldást választja, és csak akkor nyúl az erőszak eszközéhez, ha várható veszteségei a valódi demokrácia visszatérésével aránytalanul nagyok lennének.

Érvelésünket végül néhány történelmi példával gazdagítjuk, amelyek alapvető vonásaikat tekintve kívánkoznak ide, ám mélyreható elemzés hiányában elsősorban csak illusztrációként szolgálnak. Indiát függetlensége elnyerése után a világ legnagyobb demokráciájaként aposztrofálták, és valóban: ez az az ország, ahol egy-egy választás során a legtöbben járultak az urnákhoz. Az Indiai Nemzeti Kongresszus (röviden: a Kongresszus Párt) a jelenlegi politikai struktúra legrégebbi szerveződése, története messze a birodalmi időkbe nyúlik vissza. A függetlenségi törekvések fö zászlóvivőjeként már az 1920-as, 1930-as években igen népszerü volt, nem véletlen, hogy az első szabad választásokon nagyarányú győzelmet aratott. Sikereinek fö összetevői szervezettsége és erős helyi kötődése, szoros kapcsolata a nagyipar képviselőivel, valamint karizmatikus vezető egyéniségei (köztük Nehru) voltak.

\footnotetext{
${ }^{19}$ Elég csak összevetni a szocialista tervgazdaságok és a demokratikus piacgazdaságok második világháború utáni teljesítményét, vagy Kína, illetve India reformok előtti és utáni gazdasági eredményeit.
} 
A párt 1947-től egészen 1977-ig volt megszakítás nélkül, azóta pedig megszakításokkal hatalomban. Egyértelmü ugyanakkor, hogy azok a tényezők, amelyek révén az 1960-as, 1970-es években még sikerült népszerüségét növelnie (nagy állami beruházások, kiterjedt államosítások), az 1980-as években már komoly hátrányt jelentettek, mivel a gazdasági növekedés messze elmaradt a várttól, a politikát és a gazdaságot pedig hatalmas korrupció járta át (Chai-Roy [2006]). Ennek következményeként a párt kikezdhetetlennek tűnő dominanciája fokozatosan eltünt, belső szakadások gyengítették meg, és az 1990-es évekre kialakult egyfajta váltógazdaság a Bháratíja Dzsanata Párttal.

Indiában tehát a domináns párt kezdeti előnye, a klientúrarendszer, az erős személyi függőségek, valamint a jelentős mértékű központi kiadások együttesen járultak hozzá az áldemokrácia kialakulásához, míg a demokratizálódást a túlzott járadékteremtés kedvezőtlen gazdasági és politikai hatásai, valamint a gazdasági fejlődés következtében egyre hangsúlyosabbá váló helyi érdekeket képviselö politikai erők megerősödése kényszerítette ki (Wilkinson [2007]).

Indiához hasonlóan egyoldalú képet mutat Japán politikai élete is az amerikai megszállás után. A japán Liberális Demokrata Párt (röviden: LDP) 1955-től kezdödően mind a mai napig gyakorolja a hatalmat (leszámítva egy 11 hónapos intermezzót 1993-1994-ben, valamint egy hosszabbat 2009 és 2012 között). Annak ellenére sikerült dominanciáját fenntartani, hogy a párt választási eredményei sokszor egyáltalán nem voltak meggyőzők. Több olyan választás is volt, amikor a szavazatoknak csak kevesebb mint a felét tudták megszerezni. Helyi jelöltjeik azonban szinte mindig felülmúlták vetélytársaikat, ami elsősorban a japán politikai rendszer erös klientúra jellegére, a források központi elosztására és az ellenzéki pártok helyi politikai életre gyakorolt csekély befolyására vezethető vissza (Scheiner [2006]). A japán áldemokrácia gyengülését is az 1980-as évek relatíve gyenge gazdasági eredményei és komoly korrupciós botrányok kezdték ki. Az LDP-nek ennek ellenére sikerült megöriznie pozícióit, és 2012-re úgy visszatérnie a hatalomba, hogy 2009-ben a parlamenti mandátumoknak csupán egynegyedét szerezte meg. Úgy tűnik tehát, hogy a klientúrarendszer ereje és a személyes kapcsolatok továbbra is döntö befolyással vannak a japán hatalmi struktúra alakulására.

Nem véletlen, hogy Olaszországban, ahol a klientúrarendszer talán még erösebb, mint akár Indiában, akár Japánban, és emellett a költségvetés is meglehetősen centralizált, szintén sikerült egy pártnak - a Keresztény Demokrata Pártnak (DC) évtizedekig a hatalomban maradnia. A párt 1946-tól 1994-ig (többször koalícióban), közel 50 évig állt az ország élén. A DC gyökerei szintén a háború előtti időkig nyúlnak vissza, de igazi sikereit a háború befejeztével aratta, nem utolsósorban a katolikus egyház és az Egyesült Államok hathatós segítségével. Mivel fö ellenlábasa, a Kommunista Párt egyik támogatója szemében sem volt szalonképes, a DC jelentős járadékokra tett szert, hogy kiépítse klientúráját. A párt befolyása az évtizedek során nemcsak északon maradt erős, de délen is egyre nőtt, amíg a korrupció burjánzása, különböző politikai botrányok és gyengülő gazdasági eredmények végül a párt széthullásához vezettek (Rhodes [1997]). Ezzel párhuzamosan pedig a DC klientúrája átkerült más pártokhoz (elsősorban az Északi Ligához). 
Végül, utolsóként meg kell említenünk Magyarországot is. Nem elsősorban azért, mert a korábban felsorolt országokkal olyan szoros hasonlóságot mutatna, hanem mindenekelött azért, mert a jelenlegi magyar rendszer igen érdekes, modellünk szempontjából pedig nagyon tanulságos. Elképzelhető, hogy egy tipikus áldemokrácia kialakulásának vagyunk tanúi, de az is lehetséges, hogy csupán egy igen nagy támogatottságú politikai erő felvirágzásának és letünésének. Sok tényező utal azonban arra, hogy Magyarországon minden körülmény megtalálható ahhoz, hogy áldemokrácia alakuljon ki, vagy ha bizonyos feltételek még nem is adottak, azt a 2010 óta hatalmon lévő jobboldali pártszövetség megteremti magának.

A baloldal súlyos, történelmi veresége után az új vezetés gyors tempóban kezdett hozzá az áldemokrácia legfontosabb feltételeinek létrehozásához. Széles körü klientúraépítés, költségvetési centralizáció, hatalmas állami megrendelések, államosítások, minden mást elsöprő kormányzati kommunikáció jellemezte tevékenységét, valamint az alkotmány és a választási törvény számára kedvező módosítása. ${ }^{20}$ Mindezek a törekvések - miközben a baloldal láthatóan képtelen felülkerekedni saját belharcain - könnyen vezethetnek oda, hogy a jobboldal számos választást nyer majd még meg anélkül, hogy feladná a szabad választások és a demokrácia formális szabályait. Kérdés azonban, hogy ebben az esetben a növekvő járadékok meddig lesznek majd képesek ellensúlyozni az előbb-utóbb várhatóan gyengülő gazdasági teljesítményt, azaz meddig marad meg az áldemokrácia.

\section{Összefoglalás és kitekintés}

Tanulmányunkban egy olyan rendszerrel foglalkoztunk, amely köztes helyet foglal el a demokrácia és az autokrácia között, mindkettő jegyeit magán viseli, és amelyet éppen ezért áldemokráciának neveztünk. A rendszerek müködési sajátosságait a járadékok szemszögéből vizsgáltuk, és arra voltunk kíváncsiak, hogy mi magyarázza azt a jelenséget, hogy bizonyos demokratikus országokban egyes hatalmi csoportosulásoknak sikerül huzamosabb ideig magukhoz ragadni a hatalmat, miközben a politikai ellenzék gyakorlatilag megszűnik számottevő tényező lenni. Egy egyszerü modellt használtunk elemzésünkben, amelynek segítségével összekapcsoltuk a gazdaságban megfigyelhető járadékteremtést a szavazatok maximalizálásának céljával.

Mindenekelőtt megállapítottuk, hogy a járadékteremtés demokráciákban is megfigyelhető (jóllehet sokkal kisebb mértékben, mint autokráciákban), és a hatalmon lévők akkor járnak el optimálisan rövid távon, ha a monopólium részarányát úgy állapítják meg, hogy az elérhető többletszavazatok száma maximális legyen. Számos szerző mutat rá arra (például Kitschelt-Wilkinson [2007], Wilkinson [2007] vagy Scheiner [2006]), hogy a járadékok segítségével megvalósított szavazatszerzés azokban az országokban a leghatékonyabb, ahol a politikai rendszer müködését alapvetően

${ }^{20}$ Érvelésünket jól alátámasztja az a megfigyelés is, amely szerint a kormányzati propaganda és kommunikáció célpontja Magyarországon elsősorban a hatalmon lévők saját szavazótábora, nem pedig más - főleg baloldali - szavazók megnyerése. 
befolyásolják a pártok klientúrái, valamint a helyi fejlesztések finanszírozása nagymértékben függ a központtól. Ezekben az országokban sokszor tapasztalható bizonyos csoportok (pártok) egyeduralkodóvá válása és a politikai rendszer torzulása.

Modellünk segítségével azt is sikerült kimutatni, hogy amennyiben a domináns pozícióban lévő kormányzat számára a rövid távú szavazatmaximalizálás helyébe a többletjáradékok maximalizálása lép, racionális döntés a monopolszektor részarányának jelentős növelése esetleges hosszú távú előnyök elérése érdekében. Ha pedig a többletjáradékot politikai előnyök kovácsolására, a demokratikus intézményrendszer meggyengítésére vagy az ellenzék visszaszorítására használják fel, egy olyan demokrácia és autokrácia között elhelyezkedö rendszer jön létre, amelyet áldemokráciának hívtunk. A hosszú távú előnyök elérésének fő eszköze a klientúra kiszélesítése, megerősítése és elmélyítése, melyet a felhalmozódó többletjáradék segítségével finanszírozhatnak, és bár a fokozott járadékteremtés gazdasági (csökkenő reáljövedelem és jólét) és politikai (csökkenő szavazatszám) hátrányokat is okoz, a politikai bázis (klientúra) megerősítése végső soron kifizetődik, mivel nem jár az újraválasztási esélyek jelentős csökkenésével.

Történelmi példák is bizonyítják, hogy valódi verseny nélkül a politikai elit számon kérhetősége és elszámoltathatósága csorbát szenved, a fékek és egyensúlyok rendszere kevésbé hatékonyan működik, a járadékok szintje megemelkedik, a klientúraképzés pedig megerősödik. Az áldemokráciák kialakulásához általában valamilyen nagy horderejü esemény vezet, mely után csak egy komoly politikai erő marad a porondon. Így volt ez Indiában, Japánban, Olaszországban és Magyarországon is. Magyarország kivételével (ahol tulajdonképpen még az sem biztos, hogy áldemokráciával van-e dolgunk) mindenhol megfigyelhető volt az egyeduralkodó párt felemelkedése, hosszú ideig tartó tündöklése és lassú letűnése. Fontos tanulság, hogy egyik említett országban sem került sor végül autokratikus fordulatra, a változás a pártverseny fokozatos visszatérésével egyidejűleg ment végbe, és a bukást mindenhol a fokozott járadékteremtéssel együtt járó gazdasági visszaesés, csökkenő versenyképesség és elburjánzó korrupció kényszerítette ki. Ennek fényében úgy tűnik, hogy bár az áldemokráciák hosszú ideig életképesek maradhatnak, végzetüket nem kerülhetik el.

Az áldemokráciák járadékok szemszögéből történő politikai gazdaságtani vizsgálata ugyanakkor más következtetésekre, illetve kínálkozó kutatási irányokra is rávilágít. Hatékony eszköz lehet mindenekelőtt a járadékteremtés és klientúraépítés folyamatának vizsgálata autokratikus országokban is, hiszen ezekben a járadékok felhasználása és a politikai élet manipulálása nagyon hasonlít az áldemokráciákban tapasztaltakhoz, csak általában jóval magasabb annál. Különösen érdekesnek tűnik a járadékok szempontjából megvizsgálni olyan autoriter rendszerek demokratizálódási folyamatát, amelyekben a változásokat többek között világgazdasági sikerek kényszerítették ki (például Tajvan vagy Dél-Korea), mivel számos érdekes következtetést vonhatunk le Kínával, Vietnammal, de még Szingapúrral kapcsolatban is.

Végül, az áldemokráciák vizsgálata azért is fontos, mivel szükebb környezetünkben, Kelet-Közép-Európában a legkülönbözőbb politikai rendszerek működnek, többségükben nem, vagy csak részben demokratikus módon, miközben az 
aktuálpolitika és a sajtó által igen sokszor alkalmazott fekete-fehér megközelítés nem alkalmas müködésmódjuk, érdekviszonyaik, valamint a gazdaság és a politika összefonódásának alaposabb feltárására.

\section{Hivatkozások}

Abdukadirov, S. [2010]: The problem of political calculation in autocracies. Constitutional Political Economy, Vol. 21. No. 4. 360-373. o. http://dx.doi.org/10.1007/s10602010-9089-1.

Acemoglu, D.-Robinson, J. A. [2005]: Economic Origins of Dictatorship and Democracy. Cambridge University Press. New York, http://dx.doi.org/10.1017/cbo9780511510809.

Acemoglu, D.-Robinson, J. A. [2013]: Miért buknak el nemzetek? A hatalom, a jólét és a szegénység eredete. HVG Kiadói Rt., Budapest.

Brough, W. T.-Kimenyi, M. S. [1986]: On the Inefficient Extraction of Rents by Dictators. Public Choice, Vol. 48. No. 1. 37-48. o., http://dx.doi.org/10.1007/bf00239558.

ChaI, J. C. H.-Roy, K. C. [2006]: Economic Reform in China and India. Development Experience in a Comparative Perspective. Edward Elgar Publishing, Cheltenham, http://dx.doi. org/10.4337/9781845429874.

Desai, R. M. Olofsgard, A. Yousef, T. M. [2009]: The Logic of Authoritarian Bargains. Economics \& Politics, Vol. 21. No. 1. 93-125. o., http://dx.doi.org/10.1111/j.1468-0343. 2008.00337.x.

Downs, A. [1990]: Politikai cselekvés a demokráciában. Közgazdasági Szemle, 37. évf. 9. sz. 993-1011. o.

Fukuyama, F. [2014/1992]: A történelem vége és az utolsó ember. Európa Könyvkiadó, Budapest.

GandhI, J. [2008]: Political Institutions under Dictatorship. Cambridge University Press, New York, http://dx.doi.org/10.1017/cbo9780511510090.

Gandhi, J.-Przeworski, A. [2006]: Cooperation, Cooptation, and Rebellion Under Dictatorships. Economics and Politics, Vol. 18. No. 1. 1-26. o., http://dx.doi.org/10.1111/j.14680343.2006.00160.x .

Hayek, F. A. [1995]: Piac és szabadság. Közgazdasági és Jogi Könyvkiadó, Budapest.

Hess, S. [2013]: Authoritarian Landscapes. Popular Mobilization and the Institutional Sources of Resilience in Nondemocracies. Springer, New York, http://dx.doi.org/10.1007/978-14614-6537-9.

Kitschelt, H.-Wilkinson, S. I. (szerk.) [2007]: Patrons, Clients, and Policies. Patterns of Democratic Accountability and Political Competition. Cambridge University Press, Cambridge, http://dx.doi.org/10.1017/cbo9780511585869.

KorNAI János [2011]: Gondolatok a kapitalizmusról. Akadémiai Kiadó, Budapest.

Mousseau, M. [2012]: Capitalist Development and Civil War. International Studies Quarterly, Vol. 56. No. 3. 470-483. o. http://dx.doi.org/10.1111/j.1468-2478.2012.00734.x.

Murphy, K. M.-Shleifer, A.-Vishnys, R. W. [1993]: Why Is Rent-Seeking So Costly To Growth? American Economic Review. Papers And Proceedings, Vol. 83. No. 2. 409-414. o. http://dx.doi.org/10.1007/978-3-540-79247-5_11.

North, D. C.-Wallis, J. J.-Weingast, B. R. [2009]: Violence and Social Orders. A Conceptual Framework for Interpreting Recorded Human History. Cambridge University Press, Cambridge, http://dx.doi.org/10.1017/cbo9780511575839. 
RHodes, M. [1997]: Financing party politics in Italy: A case of systemic corruption. West European Politics, Vol. 20. No. 1. 54-80. o. http://dx.doi.org/10.1080/01402389708425175.

Rigger, S. [1999]: Politics in Taiwan. Voting for democracy. Routledge, London, http://dx.doi. org/10.4324/9780203449028.

Rowley, C. K.-Tollison, R. D.-Tullock, G. (szerk.) [1988]: The Political Economy of Rentseeking. Springer, New York, http://dx.doi.org/10.1007/978-1-4757-1963-5.

Scheiner, E. [2006]: Democracy Without Competition in Japan. Opposition Failure in a OneParty Dominant State. Cambridge University Press, Cambridge, http://dx.doi.org/10.1017/ cbo9780511610660.

SEKeris, P. G. [2011]: Endogenous elites: power structure and patron-client relationships. Economics of Governance, Vol. 12. No. 3. 237-258. o. http://dx.doi.org/10.1007/s10101010-0093-8.

TAYLOR, B. D. [2011]: State Building in Putin's Russia. Policing and Coercion after Communism. Cambridge University Press, Cambridge, http://dx.doi.org/10.1017/cbo9780511974144.

Tullock, G. [1988]: Rents and Rent-seeking. Megjelent: Rowley és szerzőtársai (szerk.) [1988] 51-62. o. http://dx.doi.org/10.1007/978-1-4757-1963-5_4.

WAdE, R. [2010]: After the Crisis: Industrial Policy and the Developmental State in LowIncome Countries. Global Policy, Vol. 1. No. 2. 150-161. o. http://dx.doi.org/10.1111/j.17585899.2010.00036.x.

WiLKINSON, S. I. [2007]: Explaining changing patterns of party-voter linkages in India. Megjelent: Kitschelt-Wilkinson (szerk.) [2007] 110-140. o., http://dx.doi.org/10.1017/ cbo9780511585869.005.

Zakaria, F. [1997]: The rise of illiberal democracy. Foreign Affairs, Vol. 76. No. 6. 22-43. o. http://dx.doi.org/10.2307/20048274. 